\title{
The Effect of Tourism and Market Institutional Policies on Tourist Visits from ASEAN Countries
}

\author{
Antonius Budisusila ${ }^{1}$, Albertus Maqnus Susilo ${ }^{2}$, JJ. Sarungu ${ }^{2}, \&$ Vincent Hadi Wiyono WS ${ }^{2}$ \\ ${ }^{1}$ Faculty of Economics, Economics Study Program, Sanata Dharma University, Yogyakarta, Indonesia \\ ${ }^{2}$ Faculty of Economics and Business, Sebelas Maret University, Surakarta, Central Java, Indonesia \\ Correspondence: Antonius Budisusila. Tel: 62-274-562-383. E-mail: abudisusila@gmail.com
}

Received: April 22, 2019

doi:10.5539/ass.v15n8p13
Accepted: June 17, 2019 Online Published: July 23, 2019

URL: https://doi.org/10.5539/ass.v15n8p13

\begin{abstract}
Tourism industry has experienced a significant development. This can be seen from several indicators, such as the number of foreign and domestic tourist visits, tourist spending, employment opportunities and the tourism sector's contribution to national income (GDP). Indonesian Tourist Policy has been combined with Law No.10 of 2009 concerning Tourism, and operationalized by Government Regulation No. 50 of 2011 concerning the National Tourism Development Master Plan (RIPPARNAS). It coincides with the ASEAN liberalization policies. Previous economic tourism research has not accommodated the role of economic institutions as a determinant of foreign tourism demand in Indonesia. This study focuses on tourism demand from ASEAN countries. The model is expected to explain the optimization of tourism resources for development. This data panel study revealed that Fixed Effect Model (FEM) is the most appropriate econometrical model used to estimate tourism in Indonesia in ten years (2006-2015). This study revealed some similarities with previous studies, especially in strengthening the theory of demand. The relative cost of tourism which tends to be more efficient will increase the number of tourist visits. Access to communication infrastructure and the proportion of city residents in the country of origin will increase tourism demand to Indonesia. Liberalization of policies need not be feared by many people, because the institutional aspects of the market which include rules, regulations, fiscal strength and market openness will encourage the acceleration of tourism. However, this study found that tourism services in Indonesia are still inferior compare to those of ASEAN countries. This requires international tourism marketing that changes perceptions and develops adequate destinations to facilitate ASEAN community members. In addition, this study considers that modernization in rural areas and the strengthening of related policies are related to the implementation of tourism master plans to improve tourism optimization.
\end{abstract}

Keywords: ASEAN countries, Indonesian tourism demand, policy analysis, tourism

\section{Introduction}

Tourism is one of the most advanced sectors. It has become an industry which can increase the international income growth more than ten percent in the last ten years. The number of international tourism expenditure has reached more than US \$ 525 billion in 2014 (UNWTO, 2015). Potential tourist destinations also create numerous employment opportunities and foreign exchange which contribute to the economy of many countries. Tourism is also a means of increasing facilities and infrastructure of tourist destinations in a country. Tourism has promoted cooperation and understanding among citizens worldwide. Tourism has become a means for many countries, particularly developing countries, to increase their base income and preserve their culture heritage and tradition.

Nowadays, tourism sector plays an important role in running the national, region and local economic cycle. The decision in making tourism sector as the flagship is very reasonable since Indonesia has various natural resources, derivative products, and cultural diversity. Various policies were made for directing the tourism sector. Law No.10/2009 has clear and prudent vision, mission, and principles (Indonesian Government, 2009). Tourism development has to be laid within the sustainable development framework. Sustainability here refers to the balance between three elements, which are environmental, economic and social aspects. The implementation of this policy has shown sufficient signs of progress. First, contributions of tourism sector are strengthened by the national or regional income. Data from the Central Bureau of Statistics-Indonesia (2012) showed that the contribution of tourism sector in gross domestic product and the constant value reached 16.93 percent in 2009, increasing up to 17.30 percent in 2010, 17.74 percent in 2011, and 18.05 percent in 2012. This has made the 
tourism sector the second largest national income contributor after manufacturing industry. Second, the labour absorption of tourism sector is also strengthened. National Labour Force Survey 2013 (Central Bureau of Statistics-Indonesia, 2013) showed that this sector could absorb over 20 percent of the national work force every year from August 2009 to 2012. Tourism had been propping workforce of 20.93 percent of the work force in 2009. This capability declined slightly to 20.73 percent in 2010 , and then it increased significantly to 21.33 percent in 2011. This capability is ranked the second highest after the primary sector. The third is wages improvement. Tourism sector is capable of providing a multiplier effect in the form of community welfare, either directly or indirectly, especially in developing tourist destination areas.

However, other data also show that tourism sector has not been in line with the expectation of tourism sector development. At the international level, the market segment of Indonesian tourism is only about 1.2 percent with a value of about USD 1.7 billion in 2014. The government has projected foreign exchange from all sectors of about USD 20 billion in 2020, while the tourism market reached USD 5 billion or 25 percent of the national total foreign exchange target in 2014 (Ministry of Tourism-Indonesia, 2016). The role of Indonesian tourism is still low compared to that of some ASEAN countries, especially Malaysia, Singapore, Thailand and the Philippines.

The low progress has drawn criticism and concern from many parties. The criticisms were addressed to government policies deemed ineffective in supporting national tourism competitiveness. Criticisms are aimed at the National Tourism Development Master Plan (RIPPARNAS) and ASEAN liberalization policies. Both policies are considered not effective. Anti-liberalization supporters argued that the ASEAN integration agreement: One Vision, One Identity, One Community is unsettling political jargon (Savira, 2016). Aspects and terms of liberalization, exploitation, and unemployment are the most sensitive economic, social and political issues in the country. Liberalization resulted in imported goods flowing in large quantities, threatening the local industry. Large-scale exploitation of natural resources occurs due to incoming foreign direct investments. The low competitiveness of domestic labor, education and limited productivity resulted in domestic unemployment. Similarly, Adiyati (2017) stated that the ASEAN Economic Community has created the wave of liberalization in ASEAN member states, which is not easy to cope with.

There is a serious need to examine the situation. It is useful to reduce the perspective disparity. Some national studies have examined the issue, but the studies have not been able to explicitly improve the effectiveness of these policies (Mariyono, 2017; Ulfa, 2017; Amalia, 2015). This study focuses on Indonesian tourist visits and the influencing factors. The main objective of the study is to examine to what extent RIPPARNAS and ASEAN liberalization policies affect the achievement of international tourism in Indonesia. This can be considered as the novelty of this research. The conventional factors which have been identified by previous researchers were taken into account. This study was conducted to examine the tourist visits from several ASEAN countries to Indonesia. For this study, data panel was considered relevant to be used.

\section{Conceptual Framework}

\subsection{The Function of International Tourism Demand}

The use of tourism demand theory as an instrument in tourist behaviour analysis usually puts the output measurement or quick result as a dependent variable. Several variables used to measure the results of tourism service are:

1 International Tourist Arrivals (Brakke, 2005; Botti et al., 2006, Larson, 2008; Kareem, 2008; Altin \& Uysal, 2009; Padhan, 2011; Rochester, 2011; Asemota \& Bala, 2012; Webb \& Chotithamwattana, 2013; Athanasopoulos et al., 2013; Mamula, 2015; Mei, 2015; Sinaj, 2015; Amalia, 2015; Ulfa, 2016; Mariyono, 2017)

2 Average Length of Stay (Teresa \& Amaral, 2000).

3 Visitor/Tourists Consumption Expenditure (Proença \& Soukiazis, 2005; Song et al., 2008)

The number of foreign tourists visits becomes the mostly used dependent variable compared to the length of stay and travel expenses. The study estimates that 70 percent of research on tourism demand function has applied the number of visitors (entrance) as a dependent variable. The main reason for this option is that data on travel costs or travel costs is not easy to access. This case has prompted arguments in tourism studies.

However, the use of the dependent variable with length of stay and tourist expenditure as dependent variable is sometimes also encountered. Teresa and Amaral (2000) used the length of staying in the destination country as a dependent variable to study tourism demand using the data panel approach. Visitor expenditure was also used by Proença and Soukiazis (2005) and Song et al. (2008). The use of these variables provides a more progressive analysis to ensure tourism benefits for the destination country. 
Furthermore, tourism research often focuses on the outcome and the generated impact. A sustainable tourism development paradigm encourages tourism sector. It is expected to realize the economic growth, social welfare and environmental improvement. In the study, known as Tourism-Led Growth Hypothesis (TLGH) (Georgantopoulos, 2013), economic growth must be combined with the goals of 21 agenda. In structural model, the paradigm under TLGH and agenda 21 suggests the use of multivariate analysis. It is the integration of sustainable tourism development goals or the use of simultaneous indicators as dependent variables, such as environment, economic and social indicators (Georgantopoulos, 2013).

\subsection{Factors Affecting Tourism Demand}

Many potential factors can influence tourism demand. The estimated function of demand is very diverse, depending on the situation or area used, the research period, time, type of data (time series, cross section or data panel), characteristics of tourism (holidays, business trips), and types of visits (family visits, friends, recreation and others). Proença and Soukiazis (2005), and Song et al. (2008) identified one set of potential determinants that can affect tourists' decision to travel, which include: socioeconomic factors such as income levels, relative price of origin and destination country, demographic, urbanization and the length of recreation time; technical factors associated with the convenient communication and transportation facilities; psychological factors and culture which reflect personal preference and lifestyle of potential travellers; and random factors related to unexpected events such as political instability, weather conditions, natural disasters, plagues, and so on. The variables used as explanatory variables are discussed in more detail

\subsubsection{National Income Factor (Tourist Origin)}

Average income is assumed to be the most important factor which affects someone's decision to travel. The literature has shown that orders for tourism and length of stay are directly related to income levels (personal wealth) of potential travellers and is inversely related to domestic life costs. Hence, the tourists' purchasing power is the dominant factor in explaining the current tourism and causality is expected to grow stronger (Asemota \& Bala, 2012: Webb \& Chotithamwattana, 2013).

Several different variables have been used for a proxy of the wealth level of native country's tourists. They are gross national product or gross domestic product in real terms or nominal, but it is very possible to use GDP and GNP average income. Most studies use real average income as the most accurate indicator for measuring the living standard of the origin country.

\subsubsection{Trading Volume and the Exchange Rate Level}

International trade is the trading of goods or services by the people of a country with other citizens of different countries in the world. Trade does not only include exports and imports of goods but also activities in exports and imports of services as well as also capital trade. Foreign trading has an extensive impact on the economic growth of a country, especially in developing countries. Foreign trading is determined by the work force exchange rate, consumer price index, and international trade policy on imports charge and taxes. Trading volume between native and the destination country will affect the mobility of business, and allow direct interactions between residents. The mobility of citizens due to businesses will increase tourist visits into a country (Kuncoro, 2016). On the other hand, exchange rate levels will affect trading volume. Strengthening exchange rate of the origin country to the destination country will make tourists receive a higher value of surplus consumers.

\subsubsection{Domestic Price Factor and Other Destinations}

The inclusion of prices in tourism demand functions as a result of some theoretical considerations. Tourism includes consumption of goods which have certain prices. It can also be distinguished from the competitors' destination prices or different purposes. The financial problems in the origin country lead the households to decide which product to consume on the top list, whether it is tourism product or other kinds of consumption goods. After an individual makes a decision to travel, the individual will choose a travel destination by considering other factors such as the total travelling cost and the individual will try to maximize his utilities. However, the tourist's demand does not only depend on the travel cost, but also the price of goods and alternative services as well as the general price of domestic market.

Here we need to differentiate two different situations. The first is the sender's point of view, that the increase of domestic price will lower purchasing power of potential tourists. This definitely lowers their demand to travel. On the other hand, the increase of price in the destination country makes tourists hesitate to travel to that country or allocate their visit to other cheaper destinations. In this case, these two types of prices need to be considered with regard to the tourism demand.

Some proxies which are most frequently used in tourism research are relatively and adjusted consumer price 
index (CPI), travel price index, the average level of price hotel, the ticket and travel cost, and the price of tourism package. Thus, the cost of transportation among countries can also be used as a proxy for tourism cost from the origin country to the destination country at a particular period.

\subsubsection{Infrastructure Variables}

Infrastructure becomes one of crucial discussion topics in tourism. Connectivity and accessibility are particularly important for trip and tourism business. Supporting tourism infrastructures such as roads, accommodation, transportation, communication and some other supports have an important role which determines any travelling decision. Other public investment factors in the destination country such as a fixed number of telecommunications services (cellular mobile), the level of internet use, television ownership access also determine tourists' understanding toward travelling destinations and influence any decision of the tourists.

\subsubsection{The Structure of Capital Market Industry}

Dow Jones' stock market index and logarithm index of average stock market industry are used as influential stock market in tourism demand. In a short-term (1 to 5 years), there is no clear relationship between tourism growth and moving average of stock price. Negative relationships between stock price movements and tourism growth often happen. The negative correlation between stocks and tourism growth occurs because of excessive financial market reaction compared to the revolution of real sector actual economic activities in tourism.

\subsubsection{Non-Economic Variable}

\section{Political Variable}

Politics is a proxy for improving its illegal politics, instability, and economic pressure or otherwise (Brakke, 2005). Political instability in various parts of Africa Continent has a negative effect on tourism (Kareem, 2008). Economic Sentimen Indicators will be shown and its policy implication for tourists developed by Altin and Uysal (2009).

\section{Social Variable}

Social proxy is also developed in a number of model as a form of turbulence and social phenomena that weaken and strengthen of tourism demand. In this case, some research showed some proxies, as the number of unemployment in US (Rochester, 2011), the crime rate used to measure the criminal cases in Africa continent (Kareem, 2008), and bomb attacks (Mariyono, 2017).

\section{Qualitative Variable}

Qualitative variable has form variations to be used in the model. The qualitative variables related to taste, convenient, and satisfying services should continuously be included in the development model. Qualitative measure is non-metric and often developed in the form of dummy variables. In the previous literature, for example, dummy variables were used to examine the effects and influence of qualitative variable.

\subsection{The Findings on Data Panel Analysis of Previous Research}

Some selected articles related to the use of panel data can be seen in Table 1. Important notes related to the policy variable as an explanation can be identified in the study. All studies place policies as dummy variables with various meanings. Mariyono (2017) utilized a dummy to explain the importance of providing policies that guarantee security for tourists. Chasapopoulos et al. (2014) stated that Greek policy to become an Olympic event was not favorable for tourism. Kareem (2008) found that democratic political instability impeded tourist visits to Africa. Portugal also faced a very slow process of adjusting European integration, which hampers the incoming tourist flows (Proença \& Soukiazis, 2005).

Table 1. Estimation Results of Tourism Demand Based on the Selected Former Studies (Data Panel Analysis)

This research showed that distance $\left(\mathrm{DIS}_{\mathrm{t}}\right)$ was one of the important factors that reduced the number of foreign tourists coming to Indonesia during 2002-2011. Richer and larger countries increase the number of tourists traveling to Indonesia. Bomb attacks in Bali $\left(D_{t}\right)$ reduce the number of foreign tourists. The trend of foreign tourists has fallen significantly due to bomb attacks. Tourists from western countries $\left(\mathrm{WEST}_{\mathrm{JT}}\right.$ ) visit Indonesia more than ASEAN $\left(\mathrm{ASE}_{\mathrm{jt}}\right)$. Indonesian policy must provide safety guarantees for tourists to attract more visitors. The increase in visits will lead to an increase in job creation and a share of $\mathrm{GDP}_{t}$, and ultimately strengthen Indonesia's economy according to time (T).

Chasapopoulos et al. This analysis estimates tourism demand $\left(\mathrm{TA}_{\mathrm{i}, \mathrm{j}}\right)$ with the gravity model to Greece from 7 neighboring countries. The data used were panel data during the period 2001-2010. This estimation shows that distance $\left(\mathrm{D}_{\mathrm{ij}}\right)$, income (capita GDP) and trade value $\left(\mathrm{TV}_{\mathrm{ii}}\right)$ have explanatory power more 
than the relative price $\left(\mathrm{RP}_{\mathrm{ij}}\right)$ and other determinants such as transportation infrastructure $\left(\mathrm{GI}_{\mathrm{jt}}\right)$ for travel demand to Greece. Also political stability seems to play an important role in tourism demand. An interesting finding is that the 2004 Olympics $\left(\mathrm{D}_{\mathrm{i}}\right)$ appeared to have a negative impact on international tourist arrivals in Greece that year.

This study used panel data approach with Three-Stage Least Square (3SLS) for domestic tourism in Australia during the 1999-2007. Studies showing income elasticity for domestic are negative. The national income variables are positively correlated with domestic business tourism demand. An increase in the domestic prices of travel can cause the demand for domestic trips to fall in the next one or two quarters ahead. The coefficients for lagged dependent variables are negative, indicating perhaps, that trips are made on periodic base.

This study used a panel data approach to African tourist from 20 countries during 1995-2003. He found from the analysis of this study that political instability, crime rates, exchange rate Kareem (2008) appreciation and the relative of consumer price index serve as signals for potential tourists to Africa. However, previous tourist arrivals, the number of telephone lines, the size of infrastructure, and world income positively influenced or determined the arrival of tourists to Africa.

They used panel data to estimate the demand function of tourism in Portugal during 1977-2001 by considering four main countries as major tourism suppliers (Spain, Germany, France and the United Kingdom). Dependent variable is an expenditure approach to define the demand for tourism in Portugal. Explanatory variables were per capita income-GDP $\left.\mathrm{P}_{\mathrm{ij}}\right)$, relative price $\left(\mathrm{P}_{\mathrm{ij}}\right)$, accommodation capacity in Portugal $\left(A_{t}\right)$, public investment ratio $\left(\mathrm{IP}_{t}\right), \mathrm{D}_{\mathrm{t}}$ (Europe Integration). Their empirical analysis shows that per capita income was the most important determinant of demand and accommodation capacity was the most important determinant of supply which explains the tourism movement in Portugal. The estimated dynamic panel data highlights the importance of accommodation capacity as the most important factor in attracting more tourism to Portugal. It was also shown that the adjustment process of Europe integration was slow and given the status quo it was difficult to attract more flows of tourism in the countries mentioned above.

Note: summarized from the above sources, 2017

Data panel analysis also confirms the relationship between the conventional variables and the number of tourism demand. The results show that price and tourist arrival relationship is negative. The elasticity of income is various (positive and negative). This strengthens the understanding that tourism between countries is basically competitive and zero sum games. In addition, tourism still becomes superior goods and services. The strength of data panel is the ability to display each individual or country in explaining destination's tourism demand. It is important to select the focus of the origin country to be included in the policy making.

\section{Research Method: Model Used in the Study}

\subsection{Selected Dependent Variable}

This study aims to accommodate all ASEAN countries with more ideal measures. Average length of stay, tourists' consumption expenditure and per capita tourist expenditure are ideal proxies and measurements. They can show the income of Indonesian citizens or companies related to tourists (See 2.1). However, the Central Bureau of Statistics-Indonesia only shows data on average tourism expenditure for all countries. The length of stay on Indonesia destination by international tourists is only available for 3 ASEAN countries within the period of 2006 to 2015. This limitation makes this study not ideal for selecting measurements.

This analysis used the arrival of tourists as the variable of major tourism progress. As mentioned earlier, this is not the ideal size, but has an advantage as information and data about the number of tourist arrivals from nine ASEAN countries are available. Although data for the dependent variable are available, the data for the independent variable are incomplete. The data were limited to 4 countries (Vietnam, Laos, Myanmar and Cambodia). Therefore, this study only involved five countries: Malaysia, Singapore, Thailand, the Philippines and Brunei Darussalam.

\subsection{Selected Independent Variables}

In line with the purpose of this study, to what extent domestic and ASEAN Agreement policies support the achievement of tourism development. This study selects variables that are relevant to the research problem. The first one is the National Tourism Development Master Plan (RIPPARNAS) compiled in 2009, followed by the arrangements of regional tourism master plan (RIPPARDA). This policy was actually implemented in 2011. It increased the Indonesian Ministry of Tourism's budget for the four pillars (tourism marketing, destination development, the capacity building of human and institutional resources in tourism). The average tourism development budget before the policy reached Rp.800.1 billion (2006-2010), increasing to an average of 
Rp.160.40 billion (2011-2015) or around 104.92\% (Ministry of Finance-Indonesia, 2016). The large increase shows the government's great commitment to develop tourism. However, the effectiveness needs to be examined, especially in contributing to the progress of the international tourism sector. To provide rigorous analysis of policy, the study used the RIPPARNAS policy variable as a dummy variable as there are significant differences between before and after policy.

The second, ASEAN's liberalization policy was also considered as a serious problem. There are two milestones in the liberalization policy. The first is the acceleration of the ASEAN Free Trade Area (AFTA) from 2008 to start gradually since 2003. AFTA is a form of trade cooperation among ASEAN countries to increase trade volume by decreasing tariffs to $0-5 \%$ for all sectors. Some of these policies have been effectively implemented. For example, the cooperation between Indonesia and the Philippines has eliminated tariffs in the exports of rubber, health care, textiles, wood-based and automotive goods since 2008 and 2009. The second is facing the ASEAN Economic Community in 2015. This is a form of liberalization in terms of political security, economic, social and culture. In addition to increasing trade, it can also improve the economy and social life of the ASEAN community. With the existence of ASEAN as media for cooperation, all countries in this region have the opportunity to develop. MEA also facilitates cooperation, bringing convenience in investment, infrastructure and many others (ASEAN, 2015). In positive economics term, it become economic freedom which is considered to be the way of providing the wide arena for global welfare.

Miller et al. (2018) define "economic freedom" as the fundamental right of every human to control his or her own labour and property. In an economically free society, individuals are free to work, produce, consume, and invest in any way they please. In economically free societies, governments allow labour, capital, and goods to move freely, and refrain from coercion or constraint of liberty beyond the extent necessary to protect and maintain liberty itself. It is obvious that AFTA and ASEAN Community are "economic freedom paradigm".

Furthermore, they measure economic freedom based on 12 quantitative and qualitative market institutional factors, grouped into four broad categories of economic freedom: rule of law (property rights, government integrity, judicial effectiveness); government size (government spending, tax burden, fiscal health); regulatory efficiency (business freedom, labor freedom, monetary freedom); and open markets (trade freedom, investment freedom, financial freedom). These factors may indicate significant binding constraints on economic growth and prosperity. In other words, this study can also interpret the level of economic freedom possessed by ASEAN countries; to what extent does Indonesia use ASEAN's freedom to advance tourism development? This is important to answer the doubts about ASEAN liberalization for citizen. This study considers that the two variables are the novelty of research, because previous studies have not taken the variables into account.

Mariyono (2017) also estimated international tourism demand in Indonesia using panel data consisting of 34 countries across the globe within the period of 2002-2011. The demand function was estimated based on the distance between the capital city of Indonesia to the visitor's capital city of the origin country, GDP per capita of the country of origin, visitor population, the exchange rate of US \$ to IDR, bomb attacks in Bali in 2003 and 2005, and distinguished ASEAN members and Non ASEAN (Europe and USA). Ulfa (2017) examined the relationship between per capita GDP, relative prices, substitute and accommodation prices experienced by home countries (as many as 20 countries that have the most visits for Indonesia) to demand of international tourism in Indonesia for the period 2008-2014 with data panel analysis. However, this study only considered conventional factors of demand and has not presented the dynamics of changes in the ASEAN market. Amalia (2015) has also estimated tourism demand in Indonesia from Singapore, Malaysia and Australia with the SARIMA (Seasonal Autoregressive Integrated Moving Average) approach for the 2011-1 to 2015-4 period. The research examined the demand for tourism in Indonesia based on the seasons of the three countries and seasons in Indonesia.

The previous studies used the conventional model of demand theory. It means that the conventional factors had very strong effects and researchers have confirmed the theory. This study applied the Consumer Price Index (CPI), Gross Domestic Product and Gross Domestic Product per capita. They have also considered the importance of infrastructure in tourism, especially transportation infrastructure to estimate tourism demand function.

This study also accommodates these conventional measures. However, it is important to isolate the notion of "citizen of origin". Therefore, the absolute indicator approach is used rather than relative indicators. This is to emphasize the economic behaviors of citizens of the origin country and their consequences for Indonesia. The choice of GNI per capita reflects the income generated by citizens of the country of origin, both within and outside their country within one year. This reflects the elasticity of citizens' income from requests for travel to Indonesia. Therefore, a positive sign is expected for this variable. This is also related to infrastructure. This study 
is related to communication infrastructure, which is the level of internet use (INET) in the local community. It usually has a positive relationship where the higher the citizens who have internet access, the higher the number of tourist visits to Indonesia.

However, this research also uses relative concept in price tourism, $\mathrm{CPI}_{\mathrm{ijt}}$ or relative tourist price ratio in the country of origin to Indonesian price index $\left(\mathrm{CPI}_{\mathrm{it}} / \mathrm{CPI}_{\mathrm{jt}}\right)$. This relative price variable is proxied by the consumer price index to represent costs in the country of origin to destination. $\mathrm{CPI}_{\mathrm{ijt}}$ is thought to affect the demand for travel to Indonesia. It can also be seen that the cost of living in the country of origin (5 countries) relative with the cost of living in Indonesia will affect the visit to Indonesia. This considers the price elasticity between tourism in the country of origin and the number of tourist requests to the destination country. Estimation usually produces negative coefficients. Negative price elasticity of tourist demand shows that low cost of living in Indonesia relative to other countries will increase foreign tourist arrivals.

\subsection{Data Panel Analysis}

Data panel is data which collected by cross section and tracked in a certain time-series. Data panel can also be defined as the combination of data cross section and time series. According to Baltagi (2005): (1) data panel is able to control individual heterogeneity. Individual, company, or region are heterogeneous. Data panel is able to control place and time variant while time series data and cross section are not able to control it. Research based on the time series data and cross section cannot control heterogeneity so that the result obtained is bias. (2) Data panel provides more information, variability and degree of freedom; it reduces collinearities between variables. (3) Data panel is more capable of observing the dynamics of adjustment. When cross section estimation is repeated, it can show how this condition changed over time during the observation.

A regression model is used fundamental framework of data panel analysis is as follows (Aisyah, 2012; Yap, 2011; Baltagi, 2005):

$$
\begin{gathered}
Y_{i t}=\beta_{1}+\beta_{2} X_{2 i t}+\beta_{3} X_{3 i t}+\mu_{i t} \\
i=1,2,3,4, \ldots \\
t=1,2, \ldots .20
\end{gathered}
$$

There are $\mathrm{k}$ independent variables which are observed in matrix. Those variables can change between time $(\mathrm{t})$ but do not change between individuals (i); change between i but do not change between $t$, or change between $i$ and $t$. Meanwhile, individual effects which are not observed (heterogeneity or components which are not observed/latent variable) are described in constant which contains a constant value and a set of individual or group variable which are constant throughout a certain period. $\mu_{\mathrm{it}}$ is called error (idiosyncratic error) which varies between $\mathrm{i}$ and $\mathrm{t}$. Hereinafter, there will be some variations of data panel model as follows: Pooled Regression (Common Effects Model or CEM), Fixed Effects Model (FEM), Random Effects Model or REM. In order to choose the best model, Chow Test or F-test is used. Chow test is used to choose CEM and FEM, while Hausman test is used to determine FEM and REM. This step will be used to determine the most suitable model.

\subsection{Demand Estimation Model}

The general model in this study will follow the empirical model of (Proenca \& Soukiazis, 2005; Kareem, 2008; Allen \& Yap, 2009; Chasapopoulos et al., 2014; Mariyono, 2017) which identified tourism arrivals or tourist expenditures, income effects, relative prices and infrastructure. They have studied travel requests using the data panel. However, the specific model is displayed by modifying the model to accommodate the real situation in Indonesia. This fact shows that there are institutional and tourism policy factors in tourism demand that have not been considered in their models. Therefore, this study sets the estimation model using the following formula.

$$
\operatorname{Ln}\left(\mathrm{TUR}_{\mathrm{ijt}}\right)=\alpha_{\mathrm{i} 0}+\alpha_{\mathrm{ilb}} \operatorname{Ln}\left(\mathrm{CPI}_{\mathrm{i}, \mathrm{j}, \mathrm{t}}\right)+\alpha_{\mathrm{i} 2} \operatorname{Ln}\left(\mathrm{GNI}_{\mathrm{j}, \mathrm{t}}\right)+\alpha_{\mathrm{i3}} \operatorname{Ln}\left(\mathrm{INET}_{\mathrm{j}, \mathrm{t}}\right)+\alpha_{\mathrm{i} 4} \operatorname{Ln}\left(\mathrm{FRE}_{\mathrm{j}, \mathrm{t}}\right)+\alpha_{\mathrm{i} 5} \operatorname{Ln}\left(\mathrm{URB}_{\mathrm{j}, \mathrm{t}}\right)+\alpha_{\mathrm{i} 6} \mathrm{D}_{\mathrm{it}}+\epsilon_{\mathrm{it}}
$$

Explanation:

$\mathrm{TUR}_{\mathrm{i}, \mathrm{t}}=$ The number of visits/the arrival of tourists from the native country $\mathrm{i}$ in years $\mathrm{t}$ (in thousand inhabitants)

$\mathrm{CPI}_{\mathrm{i}, \mathrm{j}, \mathrm{t}}=$ The ratio of consumer price indices of destination country (Indonesia) and origin countries $\left(\mathrm{CPI}_{\mathrm{i}, \mathrm{j}, \mathrm{t}}\right)=$ $\mathrm{CPI}_{\mathrm{it}} / \mathrm{CPI}_{\mathrm{jt}}$

$\mathrm{GNI}_{\mathrm{jt}}=$ Per capita income or Gross National Income tourists the native country $\mathrm{j}$ in years (in thousand US \$)

$\mathrm{INET}_{\mathrm{jt}}=$ the rate of internet usage per 100 people in the native country $\mathrm{j}$ in six years $\mathrm{t}$ (in \%)

$\mathrm{URB}_{\mathrm{jt}}=$ residents who live in cities in the native country $\mathrm{j}$ in six years $\mathrm{t}$ (in \%)

$\mathrm{FRE}_{\mathrm{jt}}=$ economic freedom index in the native country $\mathrm{j}$ in years $\mathrm{t}$ 
$\mathrm{D}_{\mathrm{it}}=$ domestic factor RIPPARNAS policy in years $\mathrm{t}(2006-2010=0$ and 2011-2015=1)

$\epsilon_{i t}=$ called as error (idiosyncratic error) which varies between $i$ and $t$

The analysis of data panel confirmed the relationship between price of other destinations, income and the number of tourism demand. This case strengthens the perspective of which tourism between countries are competitive and zero sum games. Moreover, it confirms that tourism still becomes superior goods and service. The excellence of data panel is that it can show each individual/country in explaining the demand on tourism destination. It is important to consider the focus on the native country to be recommendation in decision making.

\section{Empirical Data}

\subsection{Descriptive Analysis}

The international tourist visits to Indonesia, especially from ASEAN countries, are dominated by tourists from Singapore and Malaysia, each reaching 1466.01 thousand and 1138.00 thousand visits per year (Table 2). Meanwhile, the number of tourist visits from Brunei is the lowest (22.62 thousand per year), compared to Thailand (103.5 thousand annually) and the Philippines (175.50 thousand annually). The average cost of living in the country of origin can be seen in the value of the $\mathrm{CPI}_{\mathrm{ijt}}$ proxy. The highest $\mathrm{CPI}_{\mathrm{ijt}}$ is Singapore (1.05) and Brunei (1.05), and followed by Thailand (1.04), Malaysia (1.04) and the Philippines (1.01). CPI indicates the relative high cost of tourism in each country compared to Indonesia. Possibly, the cooperation between Indonesia and the Philippines made prices relatively low for both countries (see point 3.2.2.). Related to the Internet access by citizens, Singapore has the highest score (70.49\%). The lowest internet access is the Philippines (19.93\%). In terms of population living in urban areas, the country which has the highest number is Singapore $(49.52 \%)$, followed by the Philippines (42.01\%), Thailand (28.97), Malaysia (19.66\%) and Brunei (0.29\%).

Moreover, the index of economic freedom may determine the number of visits to Indonesia. This index is measured by twelve economic freedom indicators and each category is assessed on a scale of 0 to 100 . The rank of economic freedom can be seen as follows: Singapore (87.66), Brunei (67.84), Malaysia (64.90), Thailand (63.69), and Philippines (56.77). It reflects the agreement and the policy of ASEAN countries does not make the same level of openness among countries. The RIPARNAS policy is expected to encourage foreign tourist arrivals to Indonesia. This policy is proxied by using a dummy variable to determine between before and after policy. This reflects an increase in the state budget before and after the policy. The code of domestic factor, RIPPARNAS policy in years $t$ are 2006-2010 $=0$ and 2011-2015=1. Data is not displayed in the table.

Table 2. The Number of Tourists (in thousand people), The Tourism Cost, GNI Per Capita (thousand US \$), Internet Access (\%) and The Urban Citizen (\%) and The Economic Freedom Index

\begin{tabular}{|c|c|c|c|c|c|c|c|}
\hline & Country & $\mathrm{TUR}_{\mathrm{ijt}}$ & $\mathrm{CPI}_{\mathrm{ijt}}$ & $\mathrm{GNI}_{\mathrm{jt}}$ & $\mathrm{INET}_{\mathrm{jt}}$ & $\mathrm{URB}_{\mathrm{jt}}$ & $\mathrm{FRE}_{\mathrm{jt}}$ \\
\hline \multirow{3}{*}{ Brunei } & Mean & 22.62 & 1.05 & 33.62 & 52.09 & 74.77 & 67.84 \\
\hline & $\mathrm{N}$ & 10 & 10 & 10 & 10 & 10 & 6 \\
\hline & Std. Deviation & 12.77 & 0.18 & 5.72 & 10.32 & 1.07 & 2.23 \\
\hline \multirow{3}{*}{ Malaysia } & Mean & 1138.14 & 1.04 & 8.11 & 58.52 & 70.30 & 64.90 \\
\hline & $\mathrm{N}$ & 10 & 10 & 10 & 10 & 10 & 10 \\
\hline & Std. Deviation & 296.15 & 0.12 & 1.91 & 6.53 & 2.36 & 2.36 \\
\hline \multirow{3}{*}{ Philippine } & Mean & 175.50 & 1.01 & 2.49 & 19.93 & 45.63 & 56.77 \\
\hline & $\mathrm{N}$ & 10 & 10 & 10 & 10 & 10 & 10 \\
\hline & Std. Deviation & 64.97 & 0.06 & 0.67 & 14.80 & 0.24 & 1.47 \\
\hline \multirow{3}{*}{ Singapore } & Mean & 1466.01 & 1.05 & 42.41 & 70.49 & 100.00 & 87.66 \\
\hline & $\mathrm{N}$ & 10 & 10 & 10 & 10 & 10 & 10 \\
\hline & Std. Deviation & 143.27 & 0.10 & 9.67 & 7.25 & 0.00 & 0.96 \\
\hline \multirow{3}{*}{ Thailand } & Mean & 103.50 & 1.04 & 4.11 & 22.69 & 42.70 & 63.69 \\
\hline & $\mathrm{N}$ & 10 & 10 & 10 & 10 & 10 & 10 \\
\hline & Std. Deviation & 41.85 & 0.11 & 1.01 & 6.02 & 3.28 & 0.95 \\
\hline \multirow{3}{*}{ Total } & Mean & 581.15 & 1.04 & 18.15 & 44.74 & 66.68 & 68.21 \\
\hline & $\mathrm{N}$ & 50 & 50 & 50 & 50 & 50 & 45 \\
\hline & Std. Deviation & 622.83 & 0.12 & 17.43 & 22.22 & 21.30 & 11.19 \\
\hline
\end{tabular}

Source: Central Bureau Statistics-Indonesia, World Bank, Herritage Foundation, proceeded 2017 


\subsection{Model Test Using Data Panel}

The most appropriate model for the research objectives will be chosen from three models which have been estimated. The three estimated model are Common Effect Model (CEM), Fixed Effect Model (FEM), and Random Effect Model (REM) (see Table 3). The model election was done with two kinds of test used as a means for choosing data panel regression model (CEM, FEM or REM) based on the characteristics of data owned; they are F Test (Chow Test) and Hausmann Test.

Table 3. The Estimation Result of Demand with Pooled, Fixed Effect and Random Effect

\begin{tabular}{cccc}
\hline Variable & Pooled OLS & Fixed Effect & Random Effect \\
\hline Constant (C) & -2.535728 & -1.759836 & -2.530 .294 \\
LNCPI & -0.500792 & -2.995458 & -0.322308 \\
LNGNI & -1.976953 & -1.890694 & -1.977 .358 \\
LNINET & 0.756115 & 0.083634 & 0.762235 \\
LNFRE & 0.517990 & 0.207919 & 0.521559 \\
LNURB & 7.284808 & 4.354707 & 7.275 .035 \\
LNRIP & 2.498508 & -1.194500 & 2.195 .571 \\
Adj R & 0.772574 & 0.988152 & 0.834824 \\
F-Stat & 26.47771 & 376.3180 & 42.27544 \\
\hline
\end{tabular}

Source: Preceded with Eviews, 2017

Table 3 shows that the constant of all models are negative. This is not theoretically meaningful, because demand equation usually has a positive constant. Negative constants generally occur if there is a considerable range between independent and dependent variables. For example, tourist visits from Singapore and Malaysia to Indonesia are very high, and some independent variables have very low values. Negative constants can be ignored as long as the regression model tested has met the assumptions (e.g. normality for simple regression) or other classic assumptions for multiple regressions (Dougherty, 2002). In addition, as long as the slope value is not zero, there is no need to pay attention to this negative constant.

\subsubsection{F-Test (Chow-Test)}

Since the probability value of $\mathrm{F}$ Test is less than the $5 \%$ for significance level $(<0.05)$, the elected model is FEM. From Table 4, the probability value of Cross-section $\mathrm{F}$ is 0.0000 . This value is $<0.05$. Thus, we can conclude that Fixed Effect Model (FEM) is more precise compared to Common Effect Model (CEM). However, the large value of $\mathrm{F}$ in FEM does not ensure the good estimation. The study needs to conduct Hausman test to select FEM or REM (Aisyah, 2012). We will continue to calculate Hausman test (Table 5).

Table 4. F-Test: Redundant Fixed Effects Tests

Redundant Fixed Effects Tests

Equation: Antonius

Test cross-section fixed effects

\begin{tabular}{llll}
\hline Effects Test & Statistic & d.f. & Prob. \\
Cross-section F & 178.408021 & $(4,35)$ & 0.0000 \\
Cross-section Chi-square & 140.893381 & 4 & 0.0000 \\
\hline
\end{tabular}

Source: Preceded with Eviews, 2017

\subsubsection{Hausman Test}

Table 5 show the probability value of period random. If the value is $>0.05$, the elected model will be RE. In contrast, if the score is $<0.05$, the elected model will be FE.

Table 5. Hausman Test; Correlated Random Effects- Hausman Test

Correlated Random Effects - Hausman Test

Equation: Antonius

Test period random effects

\begin{tabular}{llll}
\hline Test Summary & Chi-Sq. Statistic & Chi-Sq. d.f. & Prob. \\
Period random & 64.091898 & 5 & 0.0000
\end{tabular}

** WARNING: estimated period random effects variance is zero.

Source: Preceded with Eviews, 2017 
In the table, the probability value of period random is 0.000 . This value is $>0.05$. It can be concluded that FEM is more suitable compared to REM. From those two kinds of models, it can be concluded that FE model is better than CEM and REM, even without any further tests. Hence, the following equation model is obtained:

$$
\begin{gathered}
\operatorname{Ln}\left(\mathrm{TUR}_{\mathrm{ijt}}\right)=-1.75-2.53 \mathrm{Ln}\left(\mathrm{CPI}_{\mathrm{ijt}}\right)-1.89 \mathrm{Ln}\left(\mathrm{GNI}_{\mathrm{jt}}\right)+0.08 \mathrm{Ln}\left(\mathrm{INET}_{\mathrm{jt}}\right)+0.20 \mathrm{Ln}\left(\mathrm{FRE}_{\mathrm{jt}}\right)+4.35 \mathrm{Ln}\left(\mathrm{URB}_{\mathrm{jt}}\right) \\
-1.94 \mathrm{D}_{\mathrm{it}}+\epsilon_{\mathrm{it}}
\end{gathered}
$$

The modeling shows the relationship between the price relative tourism of Indonesia and origin countries $\left(\mathrm{CPI}_{\mathrm{ijt}}\right)$ to tourist arrivals in Indonesia, where 1 percent of relative price changing in the native country will decrease Indonesia's tourism demand as many as 2.53 percent. There is sensitive response to the prices of the two countries where the cost of tourism rises in their country against the cost of tourism in Indonesia will reduce tourism to Indonesia.

This study found symptoms different from those in previous research. The rise in per capita income of the native country will increase the tourism demand. However, this study found that 1 percent of per capita income increase will decrease 1.89 percent of tourism demand. Differences among ASEAN countries have this potential deterioration. It is confirmed that Indonesia as a tourism destination in ASEAN face a service condition which is considered inferior for the high income society.

Market institution is represented by the economic freedom index. This shows that ASEAN economic freedom can be utilized by Indonesia to increase income through the number of tourist visits. Thus, worries and doubts of experts and residents were not reasonable. In term of RIPPARNAS policy, the dummy variable is enough to explain the difference in affect between before and after policy. There is strong influence on RIPPARNAS to increase tourist visits to Indonesia. The overall development of tourism in Indonesia, connected to the policy formulation and implementation of national tourism development master plan was support tourism progress.

In infrastructure, ASEAN society's ability in surfing the internet will be one of important sources and promotions for Indonesian tourism. Thus, the increase of 1 percent of citizens who access the internet will potentially increase the tourism demand as many as 0.08 percent. The citizen proportion which grows and develops in the native countries will also determine the number of tourists who come to Indonesia. Modernization of ASEAN rural areas needs to be done continuously to build travel and tourism friendly society.

\section{Conclusion and Recommendation}

This study aimed to create a model of international tourism demand in Indonesia. This data panel research found that Fixed Effect Model (FEM) was the correct econometrical model used to estimate tourism in Indonesia. This study found some similarities with the former study, especially in the strengthening of demand theory. The tourism cost which tends to be more efficient would increase the number of tourist visits. Communication infrastructure access and the citizen proportion of town/urban in the native country would increase tourism demand to Indonesia. This study considered that modernization in rural areas of ASEAN countries will increase ASEAN tourist visits to Indonesia. Market institutional aspect of policies covering the rules, regulations, fiscal power and market openness would encourage the acceleration of tourism in Indonesia. However, this study discovered that Indonesia tourism is still inferior. Strengthening policies related to the implementation of tourism master plans to improve the quality of infrastructure development of destinations and promotion in Indonesia is much needed. It will improve the good perception of ASEAN tourists for Indonesian tourism.

\section{Acknowledgement}

The authors would like to thank Ministry of Research, Technology and Higher Education, Republic of Indonesia for funding this project through Grant for Applied Product Research Program, No: 051/HB-LIT/IV/2017; April, 24, 2017. The work has been presented at the 2017 ICEBMR (International Conference on Economics, Business, Management and Research Management), Master of Management, Sanata Dharma University, Yogyakarta, Indonesia. November, 18-21 2017.

\section{References}

Adiyati, D. (2016). Efek Liberalisasi di ASEAN bagi Indonesia sebagai Negara Dunia Ketiga (The Liberalization Effect of ASEAN for Indonesia as Third World Country). Jurnal Analisis Hubungan Internasional, 5(1).

Aisyah, S. T. R. (2012). Modul Laboratorium Ekonometrika (dengan menggunakan aplikasi Eviews) Econometrics Laboratory Module (Using Eviews application). Surakarta: Economics Department-Sebelas Maret University.

Allen, D., \& Yap, G. (2009). Modelling Australian domestic tourism demand: A panel data approach. Proceeding of 18th World IMACS / MODSIM Congress, Cairns, Australia 13-17 July 2009. 
Altin, M., \& Uysal, M. (2009). Sentiment Indicator as a demand determinant in tourism: A Case of Turkey. Virginia Polytechnic Institute and State University: not publication.

Amalia, N. (2015). Forecasting International Tourism Demand in Indonesia from Singapore, Malaysia and Australia: SARIMA Approach for period 2011-1 to 2015-4 (Unpublished Thesis). Yogyakarta: Gadjah Mada University.

ASEAN (The Association of Southeast Asian Nations). (2015). ASEAN Integration in Services. Jakarta: ASEAN Secretariat, December 2015.

Asemota, O. J., \& Bala, D. A. (2012). Modeling Tourism Demand in Japan Using Cointegration and Error Correction Model. International Review of Business Research Papers, 8(2), 29-43.

Athanasopoulos, G., Deng, M., Li, G., \& Song, H. (2013). Domestic and Outbound Tourism Demand in Australia: A System-of-Equations Approach. Working Paper 06/13, February 2013. Retrieved from http://www.Buseco.Monash.Edu.Au/Depts/Ebs/Pubs/Wpapers/

Baltagi, B. H. (2005). Econometric Analysis of Panel Data. West Sussex: John Wiley \& Sons Ltd.

Botti, L., Peypoch, N., Randriamboarison, R., \& Solonandrasana, B. (2006). An Econometric Model of Tourism Demand in France. MPRA Paper No. 25390, posted 24. September 2010 14:59 UTC. Retrieved from http://mpra.ub.uni-muenchen.de/25390/

Brakke, M. (2005). International Tourism, Demand, and GDP Implications: A Background and Empirical Analysis. Undergraduate Economic Review, 1(1).

Bureau of Statistics-Indonesia. (2012). National Tourism Satellite Account (NESPARNAS) 2017. Jakarta: Bureau of Statistics-Indonesia.

Bureau of Statistics-Indonesia. (2013). National Labour Force Survey 2013. Jakarta: Bureau of Statistics-Indonesia.

Chasapopoulos, P., den Butter, F. A. G., \& Mihaylov, E. S. (2014). Demand for tourism in Greece: A panel data analysis using the gravity model. International Journal of Tourism Policy, 6. https://doi.org/10.1504/IJTP.2014.063105

De Mello, M., Pack, A., \& Sinclair, M. T. (2002). A System of Equations Model of UK Tourism Demand in Neighbouring Countries. Applied Economics, 34, 509-521. https://doi.org/10.1080/00036840110049310

Dougherty, C. (2002). Introduction to econometrics (2nd ed.). New York: Oxford University Press.

Georgantopoulos, A. G. (2013). Tourism Expansion and Economic Development: VAR/VECM Analysis and Forecasts for the Case of India. Asian Economic and Financial Review, 3(4), 464-482.

Halicioglu, F. (2004). An ARDL Model of International Tourist Flows to Turkey. In D. Kantarelis (Ed.), Global Business and Economics Review-Anthology (pp. 614-624). B\&ESI, Worcester. Retrieved from http://ideas.repec.org/p/wpa/wuwpit/0503005.htm

Indonesian Government. (2009). Law of the Republic Of Indonesia Number 10 of 2009 Concerning Tourism. Jakarta: Ministry of State Secretary-Indonesia.

Indonesian Government. (2010). Government Regulation of The Republic of Indonesia Number 50 of 2011 Concerning National Tourism Development Master Plan for the Republic of Indonesia during the period 2010-2025. Jakarta: Ministry of State Secretary-Indonesia.

Kareem, O. I. (2008). A Panel Data Analysis of Demand for Tourism in Africa. A Paper Presented At The 14th African Econometric Society Annual Conference, Held At Cape Town, South Africa (2009).

Kuncoro, H. (2016). Do Tourist Arrivals Contribute to the Stable Exchange Rate? Evidence from Indonesia. Journal of Environmental Management and Tourism, 7(1), 63-79.

Larson, S. W. M. Ng. (2008). Factors Influencing Japanese Tourism to Hawaii: A Macroeconomic Analysis (1980-2006). Capella University: Doctor Of Philosophy Dissertation.

Mamula, M. (2015). Modelling and Forecasting International Tourism Demand - Evaluation of Forecasting Performance. International Journal of Business Administration, 6(3). https://doi.org/10.5430/ijba.v6n3p102

Mariyono, J. (2017). Determinants of Demand for Foreign Tourism in Indonesia. Jurnal Ekonomi Pembangunan, $18(1), 82-92$.

Mei, L. (2015). Tourism Demand Forecasting by Improved SVR Model. International Journal of u- and e- 
Service, Science and Technology 8(5), 403-412. https://doi.org/10.14257/ijunesst.2015.8.5.38

Miller, T., Kim, A. B., \&Roberts, J. M. (2018). 2018 Index of Economic Freedom. Washington: The Heritage Foundation.

Ministry of Finance-Indonesia. (2016). The Effectiveness of the Tourism Ministry Budget Allocation on International and Domestic Tourists. Jakarta: The Indonesian General Budget Directorate.

Ministry of Tourism-Indonesia. (2016). Pocket Book of Ministry of Tourism-2016. Jakarta: Secretariat of Indonesian Tourism Ministry.

Ministry of Tourism-Indonesia. (2016). The Study of the Tourism Sectors Impacts on Indonesia's Economy. Jakarta: Secretariat of Indonesian Tourism Ministry

Padhan, P. C. (2011). Forecasting International Tourists Footfalls in India: An Assortment of Competing Models. International Journal of Business and Management, 6(5).

Proença, S. A., \& Soukiazis, E. (2005). Demand For Tourism in Portugal: A Panel Data Approach. Documento De Trabalho/Discussion Paper (February) $N^{\circ} 29$.

Rochester, L. (2011). Modelling Tourism Demand in the Caribbean: An Approach Using Spatial Econometrics. International Economics Department-Research and Economic Programming Division, Bank of Jamaica.

Savira, S. W. (2016). Dampak Positif dan Negatif MEA bagi Indonesia (Positive and Negative Impacts of the MEA on Indonesia). Jakarta: Kumparan Media Online. Retrieved from http://www.kumparan.com

Sinaj, V. (2015). Econometric modeling of demand for tourism in Albania. International Journal of Social Relevance \& Concern (IJSRC), 3(3).

Song, H., Smeral, E., Li, G., \& Chen, J. L. (2008). Tourism Forecasting: Accuracy of Alternative Econometric Models Revisited. WIFO Working Papers, No. 326.

Stucka, T. (2002). A Comparison of Two Econometric Models (OLS and SUR) for Forecasting Croatian Tourism Arrivals. Working Papers: Croatian National Bank.

Teresa, G.-M., \& Amaral, T. P. (2000). An Econometric Model for International Tourism Flows to Spain. Applied Economics Letters, 7, 525- 529. https://doi.org/10.1080/13504850050033319

Ulfa, Y. N. (2016). Determinant of International Tourism Demand in Indonesia Years of 2008-2014 (Thesis Unpublished). Department of Economics Development, Surabaya: Airlangga University.

UNWTO (United Nations and World Tourism Organization). (2015). UNWTO Annual Report 2015. Madrid, New York: UNWTO.

Vanegas, M. (2014). The Triangle of Poverty, Economic Growth, and Inequality in Central America: Does Tourism Matter? Worldwide Hospitality and Tourism Themes, 6(3), 277-292. Emerald Group Publishing Limited. https://doi.org/10.1108/WHATT-03-2014-0014

Webb, A. J., \& Chotithamwattana, C. (2013). Who Visits Thailand and Why? An Econometric Model of Tourist Arrivals by Country of Origin. Proceedings of 8th Asian Business Research Conference 1-2 April 2013, Bangkok, Thailand.

World Tourism Organization. (2015). UNWTO Annual Report 2014. UNWTO. Madrid.

\section{Copyrights}

Copyright for this article is retained by the author(s), with first publication rights granted to the journal.

This is an open-access article distributed under the terms and conditions of the Creative Commons Attribution license (http://creativecommons.org/licenses/by/4.0/). 